\title{
Advances in the Mental Control of a Robotic Hand
}

Avances en el control mental de una mano robótica

Avanços no controle mental de uma mão robótica

\author{
Iván Fernando Vargas Ochoa ${ }^{1}$ \\ Richard Camilo Bravo Angarita ${ }^{2}$ \\ César Augusto Peña Cortés ${ }^{3}$
}

Received: January $10^{\text {th }}, 2020$

Accepted:March 30 ${ }^{\text {th }}, 2020$

Available: May $4^{\text {th }}, 2020$

How to cite this article:

I. F. Vargas Ochoa, R.C. Bravo Angarita, C.A. Peña Cortés "Advances in the mental control of a robotic hand" Revista Ingeniería Solidaria, vol. 16, no. 2, 2020.

doi: https://doi.org/10.16925/2357-6014.2020.02.10

Artículo de investigación. https://doi.org/10.16925/2357-6014.2020.02.10

1 Facultad de Ingenierías y Arquitectura, Grupo de Automatización y Control - SIARC. Universidad de Pamplona. Calle 5 \# 3-93 Pamplona, Norte de Santander, Colombia.

Position: Mechatronics Engineer (c).

ORCID: https://orcid.org/0000-0002-5472-6654

E-mail: ivan.vargas2@unipamplona.edu.co

ID CVLAC: 000174893320191023156

2 Facultad de Ingenierías y Arquitectura, Grupo de Automatización y Control - SIARC.

Universidad de Pamplona.

Position: Mechatronics Engineer (c).

ORCID: https://orcid.org/0000-0002-6348-0780

E-mail: richard.bravo@unipamplona.edu.co

ID CVLAC: 00017504542019114179

3 Facultad de Ingenierías y Arquitectura, Grupo de Automatización y Control - SIARC. Universidad de Pamplona.

Position: Professor of the Department of Mechanical, Mechatronic and Industrial Engineering of the University of Pamplona.

ORCID: https://orcid.org/0000-0003-4148-2168

E-mail: cesarapc@unipamplona.edu.co

ID CVLAC: http://scienti.colciencias.gov.co:8081/cvlac/visualizador/generarCurriculoCv.do?cod_rh $=0000387487$ 


\section{Abstract}

Introduction: The present article is the product of the research "Advances in the mental control of a robotic hand", developed at the University of Pamplona in the year 2019.

Problem: Currently one of the main problems presented by robotic hand prostheses is the way in which the user indicates the movements to be performed. Given this, the best results have been obtained using invasive systems.

Objective: The main objective of the system is to allow a person to control the movements and / or gestures of a robotic hand using their thoughts, in such a way that the control is as natural and precise as possible.

Methodology: Use is made of a non-invasive, low-cost brain-computer interface (BCI) for the generation of control system references.

Results: The performance of the system is directly subject to the user's ability to recreate actions or movements in their mind; the more defined your thinking, the better the control response.

Conclusion: Mind control represents a new challenge for users, but as it is used, it becomes a more natural and precise control method, offering great control possibilities to people who make daily use of robotic hand prostheses.

Originality: Through this research, an alternative is formulated for the control of hand prostheses, which does not require invasive systems and has the advantage of being low cost.

Limitations: Frustration, stress and external noise are factors that directly affect the performance of the system.

Keywords: Mental Commands, 3D Printing, BCI Interface, Robotic Hand.

\section{Resumen}

Introducción: El presente artículo es producto de la investigación "Avances en el control mental de una mano robótica", desarrollada en la Universidad de Pamplona en el año 2019.

Problema: Actualmente uno de los principales problemas que presentan las prótesis de mano robóticas es la forma en que el usuario le indica los movimientos a realizar. Dado esto, las que mejores resultados han obtenido utilizan sistemas invasivos.

Objetivo: El objetivo principal del sistema es permitir que una persona controle los movimientos y / o gestos de una mano robótica utilizando sus pensamientos, de tal forma que el control sea lo más natural y preciso posible.

Metodología: Se utiliza una interfaz cerebro-computadora $(\mathrm{BCl})$ de tipo no invasiva y de bajo costo para la generación de referencias del sistema de control.

Resultados: El rendimiento del sistema está sujeto directamente a la habilidad del usuario para recrear acciones o movimientos en su mente. Entre más definido sea su pensamiento, mejor será la respuesta de control.

Conclusión: El control mental representa un nuevo desafío para los usuarios, pero a medida que se utiliza, se convierte en un control más natural y preciso de usar, que ofrece grandes posibilidades de control a las personas a diario hacen uso de prótesis de mano robóticas.

Originalidad: A través de esta investigación, se formula una alternativa para el control de prótesis de mano, que no requiere sistemas invasivos y brinda la ventaja de ser de bajo costo.

Limitaciones: La frustración, el estrés y el ruido externo son factores que afectan directamente el rendimiento del sistema.

Palabras clave: Comandos mentales, impresión 3D, interfaz $\mathrm{BCl}$, mano robótica. 


\section{Resumo}

Introdução: O presente artigo é produto da pesquisa "Avanços no controle mental de uma mão robótica", desenvolvida na Universidade de Pamplona no ano de 2019.

Problema: Atualmente um dos principais problemas apresentados pelas próteses robóticas de mão é a forma como o usuário indica os movimentos a serem realizados. Diante disso, os melhores resultados têm sido obtidos utilizando sistemas invasivos.

Objetivo: O objetivo principal do sistema é permitir que uma pessoa controle os movimentos e / ou gestos de uma mão robótica usando seus pensamentos, de forma que o controle seja o mais natural e preciso possível.

Metodologia: Utiliza-se uma interface cérebro-computador (BCI) não invasiva e de baixo custo para a geração de referências de sistemas de controle.

Resultados: 0 desempenho do sistema está diretamente sujeito à capacidade do usuário de recriar ações ou movimentos em sua mente; quanto mais definido seu pensamento, melhor será a resposta de controle.

Conclusão: 0 controle da mente representa um novo desafio para os usuários, mas à medida que é utilizado, torna-se um método de controle mais natural e preciso, oferecendo grandes possibilidades de controle para quem faz uso diário de próteses robóticas de mão.

Originalidade: por meio dessa pesquisa, é formulada uma alternativa para o controle de próteses de mão, que não requer sistemas invasivos e tem a vantagem de ser de baixo custo.

Limitações: Frustração, estresse e ruído externo são fatores que afetam diretamente o desempenho do sistema.

Palavras-chave: Comandos Mentais, Impressão 3D, Interface BCl, Mão Robótica.

\section{INTRODUCTION}

Today, smart prostheses are essential for people who are missing limbs and are affected by the normal development of their daily activities, both in the work environment, as well as in the family and social environment.

They have various objectives, among which are to replace and naturally emulate the movements of the missing part. The loss of a limb of the body can be the result of various factors such as an amputation of the limb due to some type of accident suffered or the fact that it does not exist partially or completely due to genetic malformations [1]. Currently, upper limb prostheses are divided into two types: mechanical and electronic prostheses. The first provides the advantage of being low cost and lower weight. On the other hand, electronic prostheses use electric actuators that are normally placed in the final effector, offering better control than the mechanical [2] and providing movements with great ease and with a greater degree of precision.

Currently, hand prostheses controlled by myoelectric signals are the most used. Its operation is based on obtaining electrical muscle signals through the use of electrodes [3], which are amplified, processed and then used to perform pattern recognition using artificial intelligence methods [4], [5]. This extracts the characteristics of the 
data and based on that information, determines the orders that must be sent to the motor controller [6]. This type of prosthesis uses two types of electrodes to capture myoelectric signals. The first is non- invasive, with the electrodes being located on the surface of the muscles. The others are invasive and require surgery to place the electrodes inside the muscles. The latter option provides the best performance, as the obtained signal is cleaner and contains less noise, but implanting electrodes also represents greater costs and risks [7].

Other prostheses are controlled through the use of a brain-computer interface $(\mathrm{BCl})$, which is a technology capable of translating the user's intentions and thoughts into device control signals in real time [8]. $\mathrm{BCl}$ systems are made up of several signal-processing blocks that process consecutively. The electrodes are strategically placed on the user (regulation 10-20) and capture the electrical activity generated by the brain at all times. This signal is amplified and preprocessed in order to eliminate the noise generated by the different devices. When the signal is already free of noise and interference, it goes to the machine learning stage. There, the characteristics of the EEG signal are found by obtaining data vectors. By classifying these data vectors, a prediction can be obtained. The classifier prediction can be used as a feedback signal by displaying it to the user of the robotic hand prosthesis [9]. The best results come from systems that use invasive BCls, which allow people with motor difficulties to control their environment or robotic extremities using only their thoughts [10], and, unlike myoelectric prostheses, these systems do not depend on the state of the muscle or amputation type. Surgical intervention is sometimes necessary to implant the sensors, representing a high risk and cost to the user. Furthermore, implanted sensors can adversely affect the body's defenses, which may even render them unusable [11].

Initially, the acquisition and use of electroencephalographic signals (EEG) focused only on the fields of medicine and psychology [12]. However, due to the technological advances that have been evidenced in recent years, the use of these signals has been taken to different fields where a great multitude of applications are made such as: controlling a wheelchair through the use of thoughts or neuromarketing systems that analyze the diverse effects on viewers before an advertising commercial [13]. Considering the large increase in the use of these brain wave capture devices, today there are many companies that are dedicated to manufacturing them to meet the needs of customers and, especially, to be able to carry this type of technology over to researchers and video game lovers. Some of the best known portable electroencephalogram devices on the market are: NeuroSky's MindSet which has a dry electrode located in position FP1, according to the International 10-20 system, and has a sample rate of $512 \mathrm{~Hz}$ [14], Muse that has 4 electrodes located on the front (F7, F8, FP1, FP2) 
and has a sampling rate of $256 \mathrm{~Hz}$ [15] and Emotiv Epoc that has 14 channels (AF3, AF4, F3, F4, FC5, FC6, F7, F8, T7, T8, P7, P8, 01, 02) for the acquisition of EEG signals, is capable of capturing 128 or 256 samples per second, has an internal frequency of $2048 \mathrm{~Hz}$ and additionally has a gyroscope for two-dimensional control [16].

The electroencephalographic signals obtained by means of a brainwave sensor are generally processed and classified by frequency bands. This allows for the extraction of patterns that may be related to the different psychological or physiological states of a person. These waves are classified as follows:

- Delta waves: These waves are directly related to the deep sleep stage. They are present in children younger than 1 year old and in adults in a state of deep sleep. Due to its low frequency, delta waves are easily confused with artifact signals that are caused by the large muscles of the neck or jaw. Its frequency varies from $0.1 \mathrm{~Hz}$ to $3.5 \mathrm{~Hz}$.

- Theta waves: Theta waves occur in states of calm. It usually happens on occasions where the person is doing a certain activity and suddenly feels immersed in a type of temporary and short fantasy. In children and adults, it occurs when they are stressed. Its variation in amplitude ranges from 20 to 100 microvolts and its frequencyis in a range of $4 \mathrm{~Hz}$ to $8 \mathrm{~Hz}$.

- Alpha waves: These waves are associated with the state of relaxation. When a person begins to perform some type of activity that requires concentration, this signal begins to become more relevant and its state changes. Its frequency is normally from $8 \mathrm{~Hz}$ to $14 \mathrm{~Hz}$.

- Beta waves: These are directly related to the state of concentration of a person when making an intention to move. Generally, this type of wave is detected in the front and central part of the brain. Its frequency is in a range of 14 to $26 \mathrm{~Hz}$.

- Gamma waves: These waves are usually the most frequent and fastest in the brain and are directly related to intense brain activities (not normal thoughts or problem solving) and can include flashes of brilliance and sudden bursts of insight / intuition and moments of extreme attention and concentration. They are in a frequency range of $30-60 \mathrm{~Hz}$. [17].

Due to the disadvantages of the current control systems for the movement control of the most modern robotic hand prostheses on the market, this work presents the development of a system that uses a low-cost non-invasive $\mathrm{BCI}$ to relate some specific thoughts of a user to the gestures and / or movements of a 3D-printed robotic hand. 
Using a program developed in Java, previously trained mental commands are detected and using a user datagram protocol, certain instructions are sent to a NodeMCU development board to take specific actions. This system provides an alternative control method to invasive systems and benefits those who, through the use of a robotic hand prosthesis, need to perform functions that are inhibited due to the lack of a limb.

\subsection{Literature review or research background}

A prosthesis is an element developed with the aim of replacing and imitating the movements of the missing part. There are currently several ways to control a robotic hand prosthesis, among which we find electromyographic signals (EMG) [18], which are electrical signals produced by the muscles during the process of contraction and relaxation. Mahmoud Tavakoli et al [19], in one of his investigations, presents a system capable of recognizing up to 4 gestures with a single-channel surface EMG signal, which can be used to control a prosthetic terminal based on predefined grip postures. However, the systems that have obtained the best results use invasive electrodes such as needles, which represent a greater cost and risk for the users. On the other hand, systems that use surface type electrodes [20] have the disadvantage that their performance is directly subject to the state of the muscle, the type of amputation and even the positioning of the electrodes [21].

Another way to control a prosthetic hand is through the use of a Brain Computer Interface $(\mathrm{BCl})$, which has advanced technologies and creates new possibilities to provide medical care solutions to people with severe motor disabilities [22]. Its operation is based on the analysis of electroencephalographic signals (EEG) to decode the movements of each finger within the same hand [23]. An interesting study was carried out by Del Castillo et al [24], in which the development of a method that selects and identifies the characteristics of the pre-movement state is presented, using a probabilistic classification algorithm, analyzing the electrophysiological state of the user's brain activity. This type of system offers the possibility that users, from a single test and without the need for personalized training, can control a neuro-prosthetic device. In the experiments carried out, the system proves to be able to predict movements with great precision and speed, since 6.6\% error rates are obtained. On the other hand, Alexandra et al [25] mention in one of their investigations the development of a method that classifies electroencephalographic signals with great precision to control the movement of a hand prosthesis. The proposed method is based on an adaptive neuro-diffuse inference system (Adaptive Neuro Fuzzy Inference System, ANFIS), which is applied to the characteristics obtained from Wavelet Transforms (TW). The 
system proved to be quite accurate. The best results were obtained with the signals generated by the motor tasks. Carlos D. et al [26] conducted another study related to the development and evaluation of SNN-based brain signal classifiers, which resulted in simple problems being solved with a smaller number of spiking neurons. Some of the disadvantages of $\mathrm{BCls}$ are that they tend to require invasive recording methods, which represent a risk for the user [27]. However, with the technological progress that has been evidenced in recent years and the interest they have aroused in the different companies in the use of $\mathrm{BCl}$, today you can find non-invasive and low-cost equipment, with good resolution, ease of use and portability [22], which provide the possibility of creating new alternatives for hand prosthesis control.

\section{MATERIALS AND METHODS}

Our Work proposes the use of the Emotiv Epoc device (Figure 1), which is a non- invasive, low cost and easily acquired brainwave sensor.

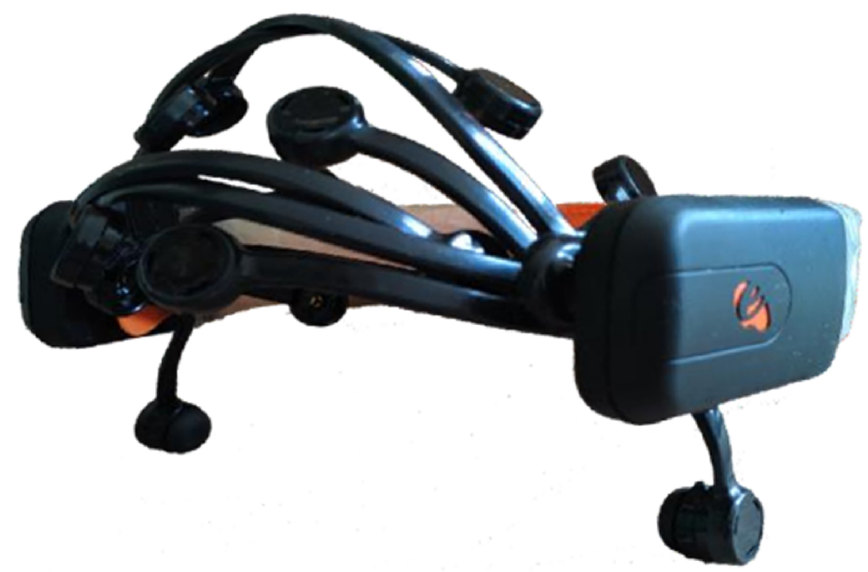

Figure 1. Emotiv Epoc device.

Source: own work

The device is capable of obtaining the signals of the 14 channels: AF3, F7, F3, FC5, T7, P7, 01, 02, P8, T8, FC6, F4, F8, AF4, based on the international 10-20 system (Table 1), which is an approved method to describe the location of electrodes on the scalp, for the registration of the EGG [28]. 
Table 1. Table with the distribution of the electrodes according to regulation 10-20 [29].

\begin{tabular}{lccc}
\hline \multicolumn{1}{c}{ Cerebral Area } & Left Hemisphere & Midline & \multicolumn{2}{c}{ Right Hemisphere } \\
\hline Frontopolar & $\mathrm{FP} 1$ & - & $\mathrm{FP} 2$ \\
\hline Frontal & $\mathrm{F} 3$ & $\mathrm{FZ}$ & $\mathrm{F} 2$ \\
\hline Fronto- Temporal & $\mathrm{F} 7 \mathrm{C3}$ & $\mathrm{CZ}$ & $\mathrm{F} 8 \mathrm{C} 4$ \\
\hline Medial Temporal and Parietal & $\mathrm{T} 3 \mathrm{P} 3$ & $\mathrm{PZ}$ & $\mathrm{T} 4 \mathrm{P} 4$ \\
\hline Posterior Temporal and Occipital & $\mathrm{T} 5 \mathrm{O} 1$ & - & $\mathrm{T} 602$ \\
\hline
\end{tabular}

Source: own work

Figure 2 graphically depicts the positioning of each of the electrodes according to regulation 10-20.

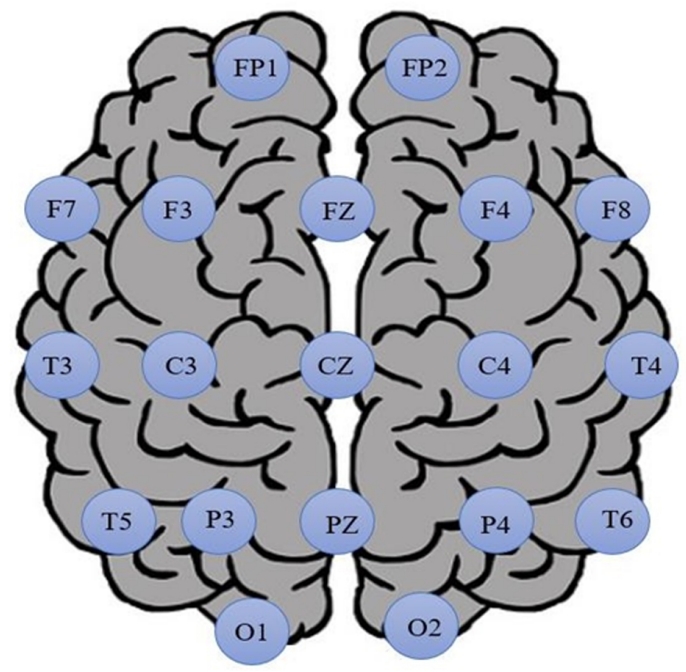

Figure 2. International 10-20 System for electrode placement. Source: own work

This device has a software development kit (SDK), which allows users to create their own applications in a simple way using programming languages such as $\mathrm{C}++$, Java, Python, C \#, among others. It also includes different suites that process the neurosignals obtained from a person. To access each of these suites it is necessary to start the graphic environment called Emotiv Control Panel.

The first suite is known as the expressive suite and identifies the facial expressions that a user makes (Figure 3). Some of the gestures that can be recognized are: look to the left, look to the right, look straight ahead, wink the left eye, wink the right eye, smile, among others. From the same suite, we can vary the detection sensitivity of 
each of these gestures in order to improve the experience. This tool can be very useful for controlling the closure of a robotic hand by simply clenching our teeth.

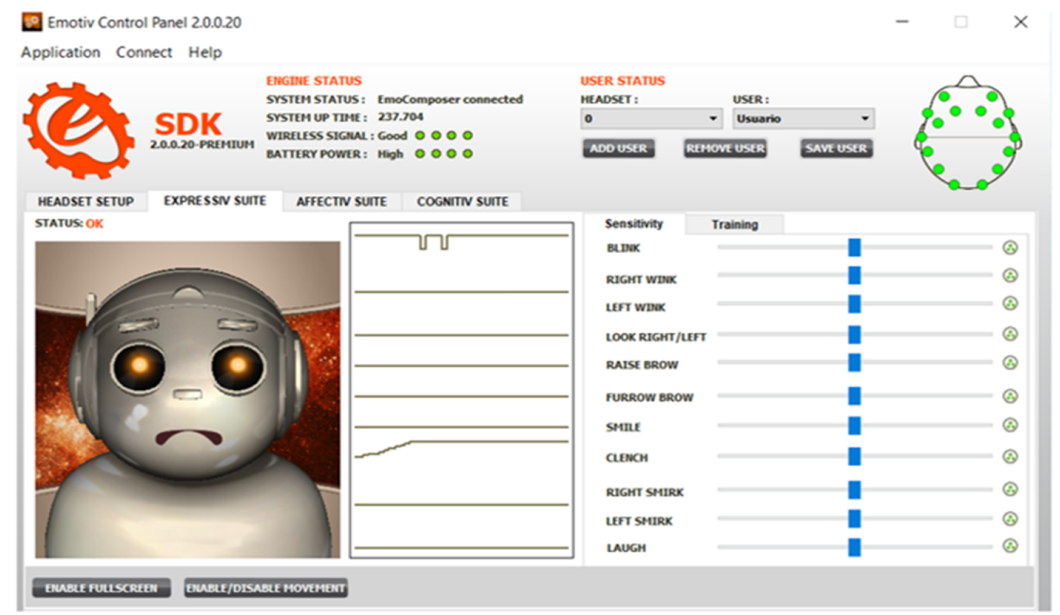

Figure 3. Expressive Control Panel Emotiv Suite.

Source: own work

The affective suite obtains information related to the emotional state of a person. This tool allows us to identify states such as: meditation, frustration, excitement, calm, attention and / or boredom. Figure 4 shows an example of capturing 2 emotional states of a user. When controlling a robotic hand, this results in the mental command only being performed when the level of attention is above a set value, avoiding involuntary movements and ensuring more precise control.

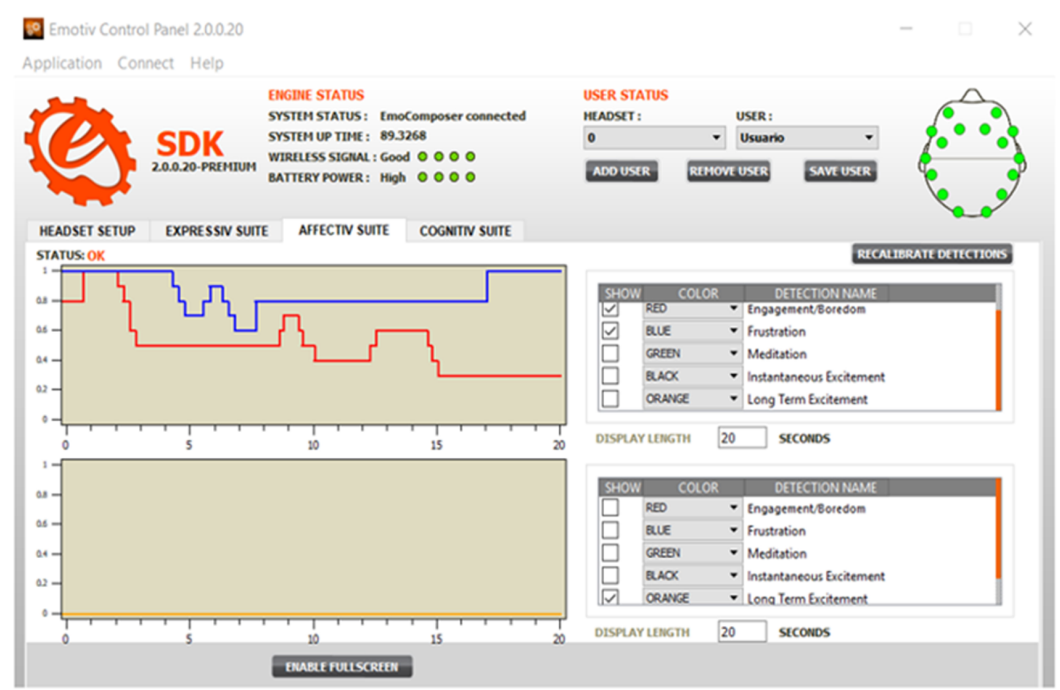

Figure 4. Analysis of emotions through the affective suite.

Source: own work 
The cognitive suite detects up to 14 mental commands related to the movement of a box, such as: push, pull, push to the left, push to the right, rotate clockwise, rotate counterclockwise, among others. In this suite it is possible to visualize the status of each of the sensors, the battery level of the device, the connection status and the training percentage (varies from 0 to 100\%) of each of the mental commands related to the movement of a box. Figure 5 shows how it is possible to push the box backwards by means of a thought.

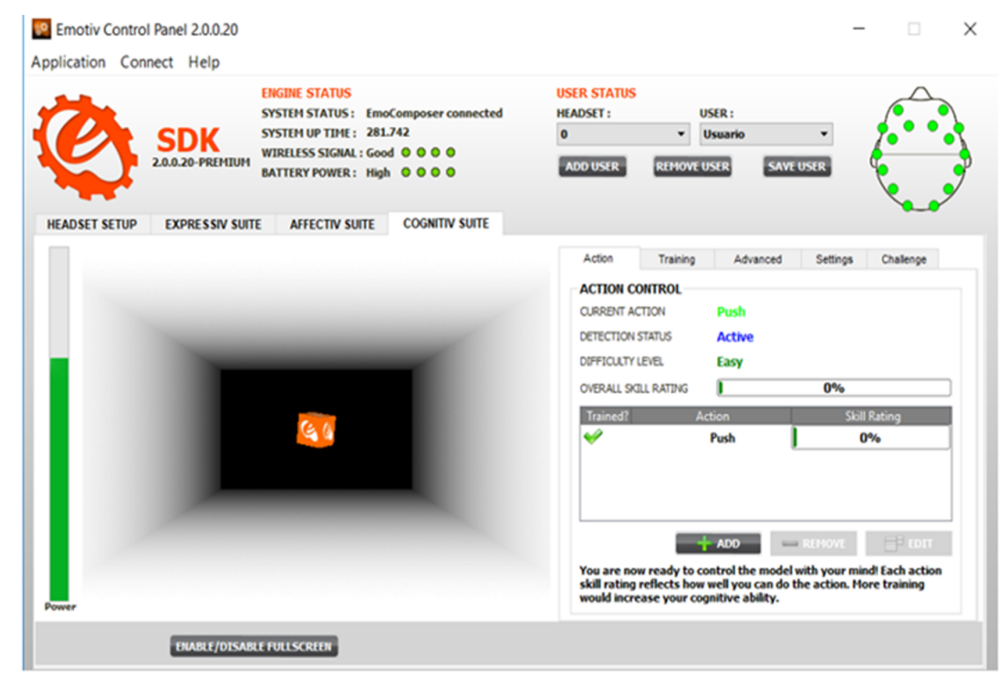

Figure 5. Cognitive control processing.

Source: own work

For the development of this project the cognitive suite is used in order to analyze brain waves that are related to specific thoughts of a user, such as thinking about closing and opening the hand, in order to generate references of control for the manipulation of the 3D-printed robotic hand.

The robotic hand used was taken from the thesis "3D Printed Myoelectric Prosthetic Arm" [30] because this hand allows movements with great ease and is easy to replicate. The material used to print the hand was PLA due to its low cost. In Figure 6 , you can see the 3D design of the robotic hand seen from the SolidWorks software, as well as a brief description of each of its pieces. 


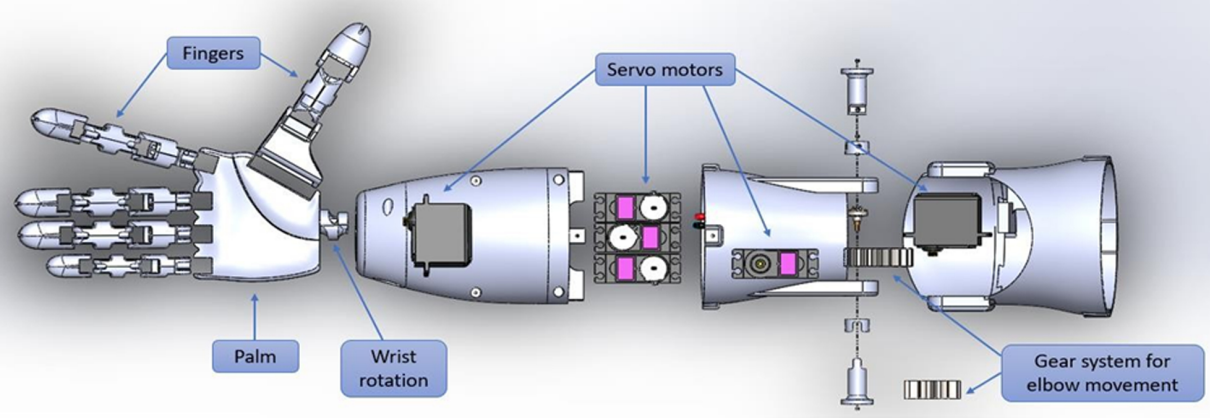

Figure 6. Robotic hand in SolidWorks.

Source: own work

In Figure 7, the replication of said robotic hand can be visualized.

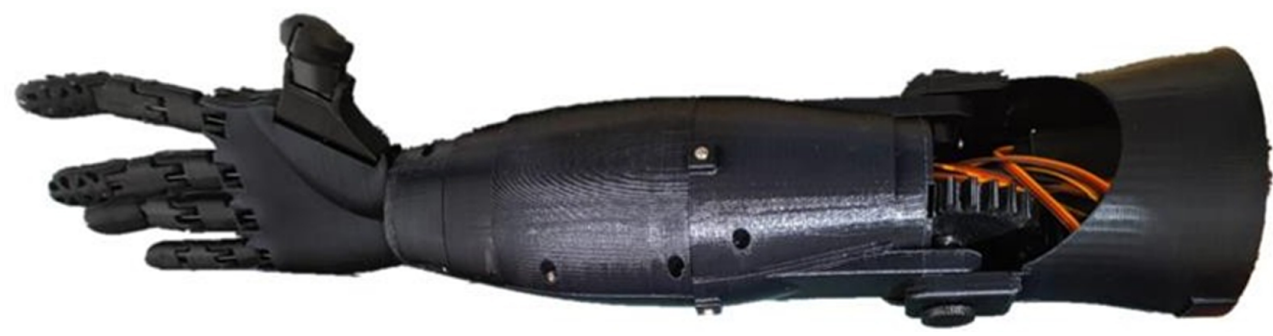

Figure 7. Robotic hand used for the development of the project.

Source: own work

It begins by reading the brain waves of each of the users and performing the respective calibration of the equipment, verifying that the contact of each of the electrodes of the device is adequate. Subsequently, a previous training of the mental commands to be used is performed. This training can vary between 15 to 25 minutes, depending on the skill level of each of the users. The trained mental commands are as follows:

- Think about opening and closing the robotic hand.

- Think about opening and closing the robotic hand and then perform a fine clamp grip.

It is understood that a fine clamp grip (Figure 8) is a movement that requires skill and coordination, using the thumb and index finger in the form of a tweezer, in order to be able to hold objects such as pencils or brushes. 


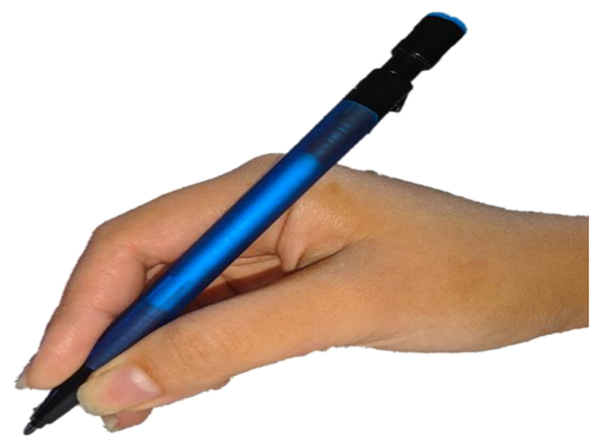

Figure 8. Fine clamp grip of a mechanical pencil. Source: own work

For each user, different strategies were used to train the proposed mental commands. Some of the users think of a specific color, other users imagine the movement of the hand in their minds. This is because each person thinks differently and the strategy used by one user may not work on another person. After training each of these mental commands to generate the control references of the robotic hand, the electroencephalographic signals acquired by the Emotiv Epoc device are sent via a Bluetooth connection to a computer or a Raspberry Pi. With the data in either of these two devices, they are processed by a program developed in Java using the software development kit (SDK), thereby detecting the thoughts of each of the users. In Figure 9, you can see the graphical interface of the developed program, which by means of text boxes allows the user to configure the IP address and port through which the instructions will be sent to the NodeMCU board, depending on the mental commands that are detected.

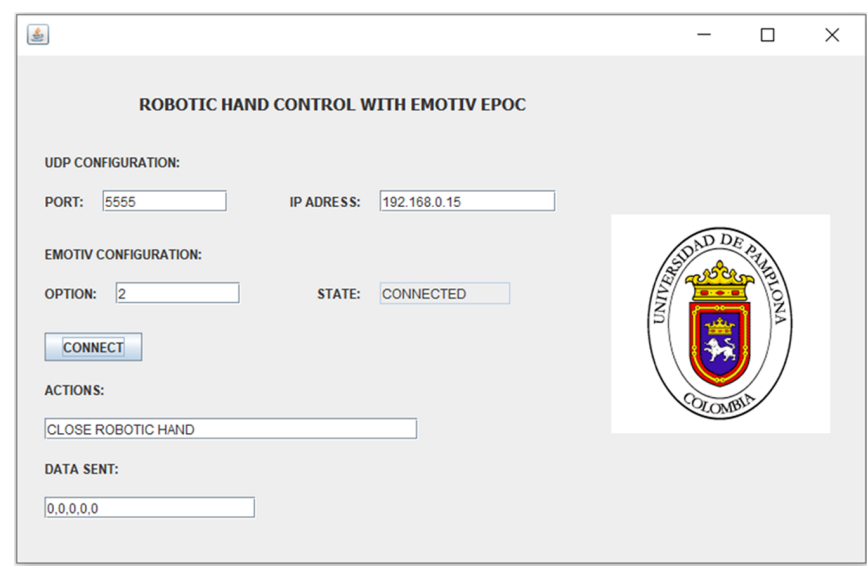

Figure 9. Graphical interface of the program developed in Java to detect mental commands.

Source: own work 
The NodeMCU is a development board that is based on ESP8266. It is currently widely used in the development of applications related to the Internet of Things (IOT). The communication that was used to send the instructions from the program developed in Java to the NodeMCU board was the user datagram protocol (UDP), which offers the advantage of being a fairly fast communication protocol. After the NodeMCU board receives the data, the position of each of the actuators of the robotic hand varies in order to achieve the movement and / or gesture associated with the mental command executed by the user. The operating architecture of the entire system can be visualized in Figure 10.

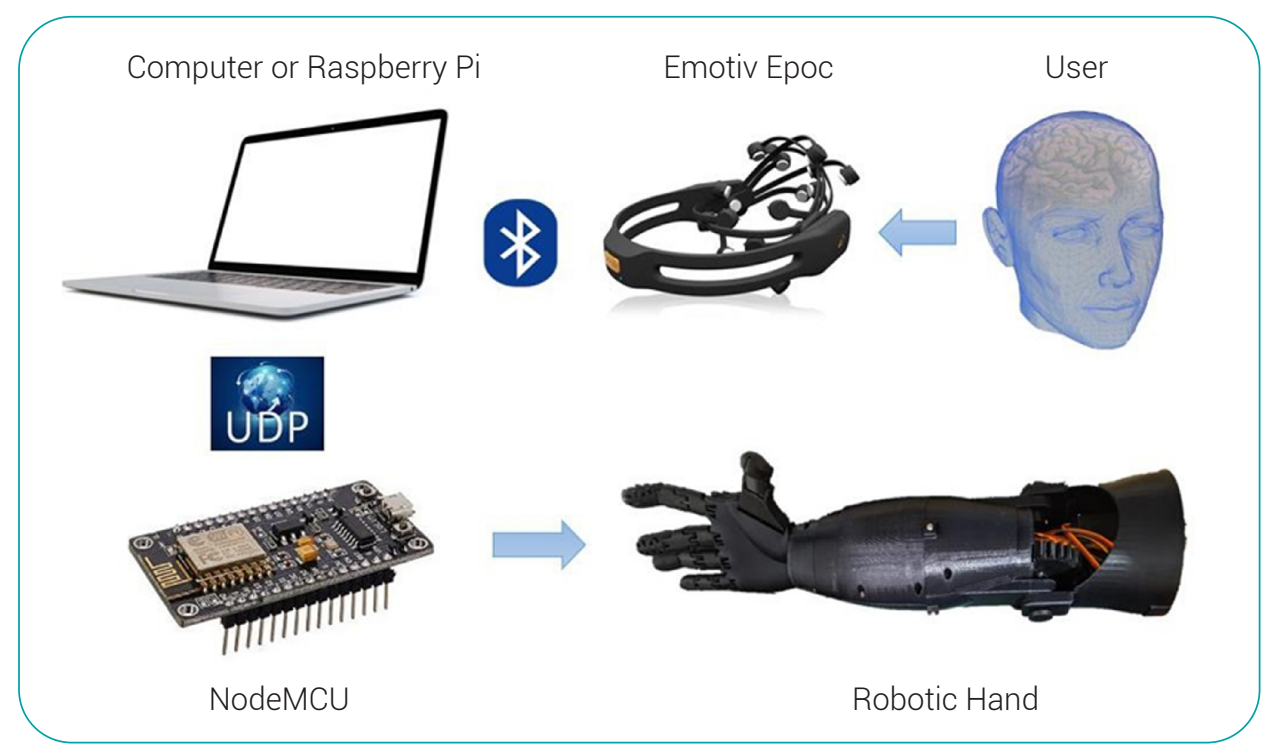

Figure 10. System architecture for robotic hand control. Source: own work

The mental commands, trained prior to the use of the system, serve as a reference for the program developed in Java. Through a communication with the Engine the cognitive suite is accessed, allowing for the comparison of the mental commands that are being executed with those that were trained. Each time a mental command is detected, a specific instruction is sent to the NodeMCU board, which varies the position of the actuators to perform the movement of the robotic hand. In the event that the logical system does not detect any type of mental command and that the person is in a neutral state, no action will be sent and it will be necessary to re-read the data that is being captured, in order to detect any changes. This flow of information can be visualized in Figure 11. 


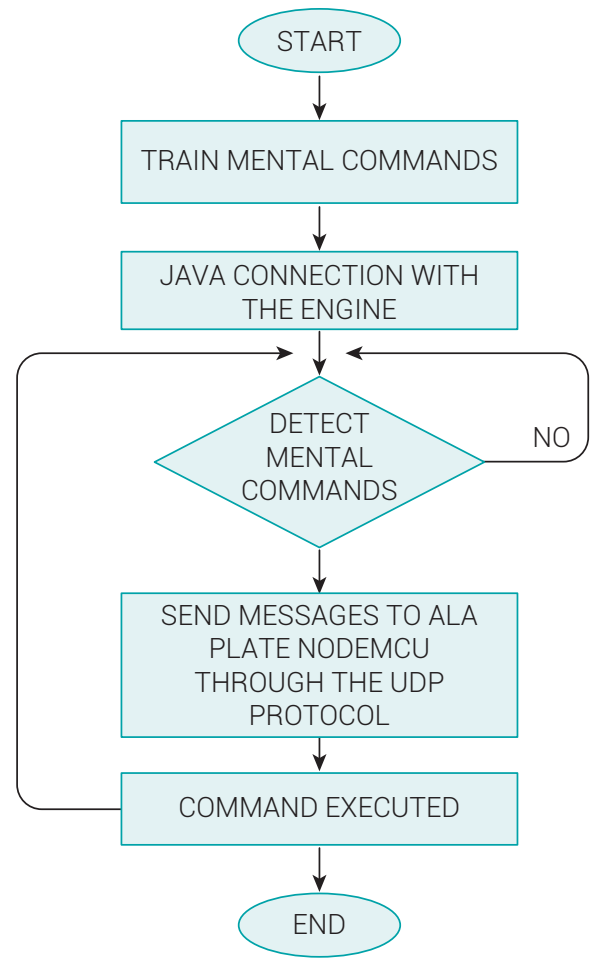

Figure 11. Flow chart of the system for the control of the robotic hand. Source: own work

\section{RESULTS}

Seven students from the University of Pamplona (between 20 and 25 years old) were selected to validate the correct operation of the system. The time taken by the users to train the mental commands was between 45 minutes and 1 hour. Some of the users quickly adapted to the use of the system, while others presented some difficulties during training. This is due to factors such as stress and frustration at not being able to execute any kind of mental command. It should be noted that the more defined the thought, the easier it will be to distinguish and process it through the developed system.

To facilitate the training of the mental commands, specific commands were trained and recreated in the robotic hand in such a way that the user could have a type of visual feedback, improving the effectiveness of the training. 


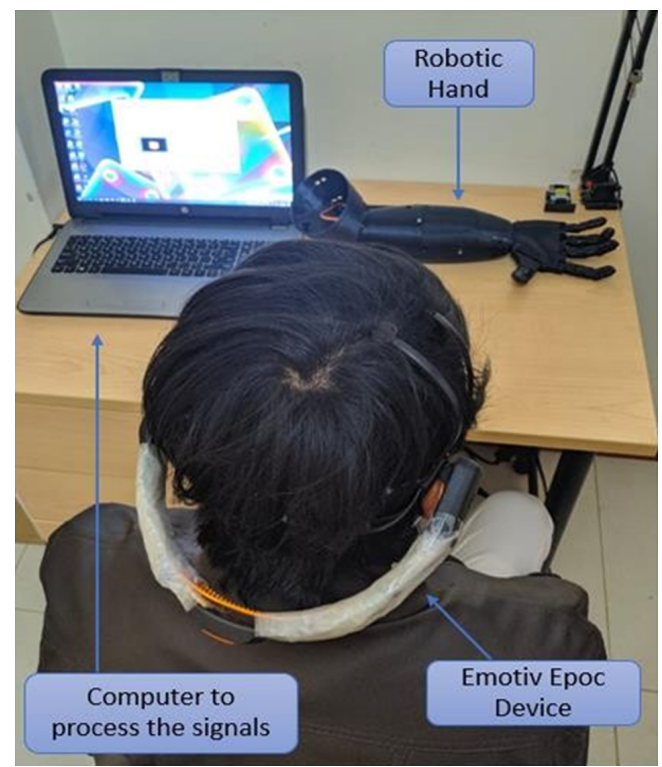

Figure 12. Tests performed on a student from the University of Pamplona. Source: own work

For each of the users, 5 tests were accomplished related to a mental script in order to determine success rate.

- Sequence 1: Open and close the robotic hand.

- Sequence 2: Open and close the robotic hand and then perform the fine clamp grip.

Table 2 shows the results related to the number of successes and failures of each user who performed each sequence. The tests are adjusted for one week, adjusting the disposition time of each user.

Table 2. Tests performed on users.

\begin{tabular}{cccc}
\hline Users & Sequence Type & Successes & Failures \\
\hline \multirow{2}{*}{1} & Sequence 1 & 4 & 1 \\
\cline { 2 - 4 } & Sequence 2 & 3 & 2 \\
\hline \multirow{2}{*}{2} & Sequence 1 & 4 & 1 \\
\cline { 2 - 4 } & Sequence 2 & Sequence 1 & 1 \\
\hline
\end{tabular}

(continúa) 
(viene)

\begin{tabular}{cccc}
\hline Users & Sequence Type & Successes & Failures \\
\hline \multirow{2}{*}{4} & Sequence 1 & 4 & 1 \\
\cline { 2 - 4 } & Sequence 2 & 2 & 3 \\
\hline \multirow{2}{*}{5} & Sequence 1 & 3 & 2 \\
\cline { 2 - 4 } & Sequence 2 & 3 & 2 \\
\hline \multirow{2}{*}{6} & Sequence 1 & 3 & 2 \\
\cline { 2 - 4 } & Sequence 2 & 1 & 4 \\
\hline \multirow{2}{*}{7} & Sequence 1 & 2 & 3 \\
\hline
\end{tabular}

Source: own work

It is evident in Figure 13 that the majority of success rates are $60 \%$ or higher, which demonstrates good system performance and good skills in most users to adapt to this type of control. User 7 obtained a percentage of $0 \%$ in Sequence 2. This is because we are not used to controlling physical or virtual objects using our thoughts and this may represent a new challenge. In addition, frustration is a very important factor in this type of control, since some users who could not move the box during the previous training in the simulator, were easily discouraged and this prevented them from moving forward.

Percentage of successes

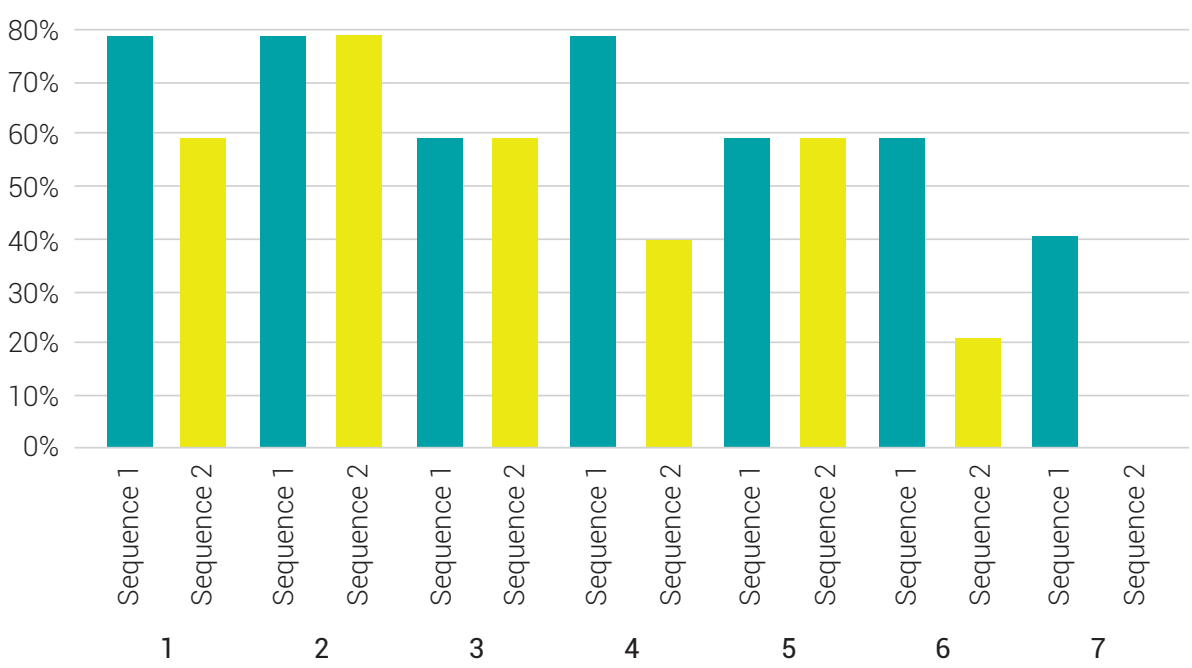

Figure 13. Bar chart of the percentage of success of each sequence.

Source: own work 
Table 3 shows some statistical indicators of the success rates obtained by each user, such as the mean and the median. An average level of success of more than $60 \%$ was evaluated for Sequence 1. This is because Sequence 1 involved fewer mental commands and the movements were much easier to visualize internally or relate to a specific color. Sequence 2 implied a higher level of concentration, as this type of movement requires a greater level of precision, such as holding a pencil.

Table 3. Statistical indices of the tests performed.

\begin{tabular}{ccc}
\hline Statistical Indexes & Sequence 1 & Sequence 2 \\
\hline Mean & $65.71 \%$ & $45.71 \%$ \\
\hline Median & $60 \%$ & $60 \%$ \\
\hline
\end{tabular}

Source: own work

In Figure 14, the results obtained from the statistical indices of Table 3 can be observed graphically; this, in order to have a better visualization of the data. It should be noted that external noise, nerves and stress are factors that can influence the performance of the system. Therefore, before beginning the necessary tests to validate the correct functioning of the system, prior training is carried out so that the user relates with and adapts to this new control system.

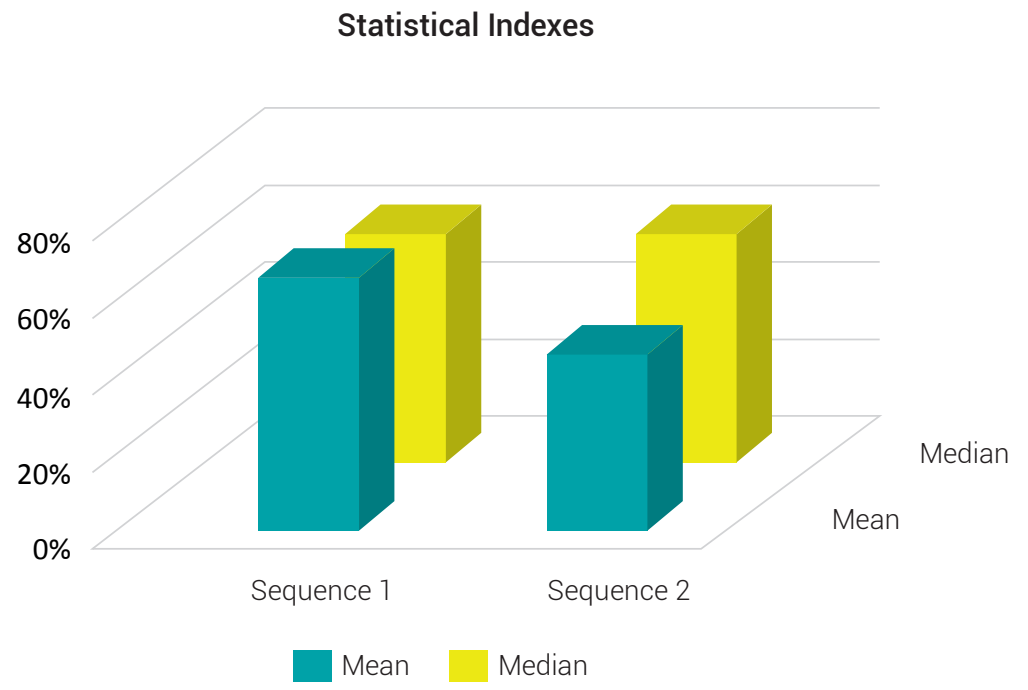

Figure 14. Bar chart of the statistical indicators of the results obtained. Source: own work 


\section{DISCUSSION AND CONCLUSIONS}

Currently, one of the main problems with robotic hand prostheses is the way in which the user indicates the movements to be performed. The prostheses that have obtained the best results use invasive systems, which represent a risk for the user, as they must undergo an expensive and delicate surgery to implant the sensors. In the case of prostheses controlled by electromyographic signals (EMG), their disadvantage is that they depend on the state of the muscle and the type of amputation. Considering the above, a system was developed that allowed for the movements of a robotic hand to be controlled by using a low-cost, non-invasive brain-wave sensor. After applying the corresponding tests to validate the correct functioning of the system, it was determined that mind control works effectively and that a good performance of the system is directly subject to the ability of the user to recreate actions or movements in their mind and to the time dedicated to training the mental commands used; the more defined your thinking, the better the control response. The good contact and positioning of the electrodes is of fundamental importance, since a bad contact can cause noise in the signals and generate errors in control.

Mind control represents a new challenge for users, but as it is used and trained, it becomes a more natural and precise process, offering great control possibilities for people who use robotic hand prostheses every day. In addition, the device used has the advantage of being economical and easily acquired and does not require any type of surgery to be able to use it. This represents a great alternative to the invasive systems that are currently used for the control of hand prostheses.

Finally, and to close, it is important to mention that even though the majority of the students have long hair, this did not represent any contact problems with the electrodes. This is due to the physical properties of hair, as it can be a good conductor and facilitates the acquisition of electroencephalographic (EEG) signals.

\section{REFERENCES}

[1] A. Tecuatl Pancoatl, "Prótesis inteligentes," Benemérita Universidad Autónoma de Puebla, pp. 12, 2014. [Online]. Available: https://edoc.pub/ensayo-protesis-inteligentes-pdf-free.html

[2] M. E. Rodríguez-García, G. Dorantes-Méndez, and M. O. M. Gutiérrez, "Desarrollo de una prótesis para desarticulado de muñeca controlada por señales de electromiografía," Rev. Mex. Ing. Biomed., vol. 38, no. 3, 2017. [Online]. doi: http://dx.doi.org/10.17488/rmib.38.3.8 
[3] J. Brazeiro, S. Petraccia, M. Valdés, “Mano Controlada por Señales Musculares," Universidad de laRepública, pp. 161, Sep. 2015. [Online]. Available: https://iie.fing.edu.uy/publicaciones/2015/BPV15/BPV15.pdf

[4] R. Agrawal, "Predictive Analysis Of Breast Cancer Using Machine Learning Techniques", Ing. Solidar., vol. 15, no. 29, 2019.

[5] D. Ramírez Jiménez and J. D. Quintero-Ospina, "Classification of pathologies present in the spinal column through learning machinery techniques”, Ing. Solidar., vol. 15, no. 27, 2019.

[6] J. M. López, G. Martí, S. T. Puente, F. A. Candelas, A. Úbeda, F. Torres, “Implementación y evaluación de un esquema de control mioeléctrico ON/OFF utilizando hardware de bajo coste," Área de Ingeniería de Sistemas y Automática, Universidad de Extremadura, pp. 94-99, 2018. [Online]. Available: http://rua.ua.es/dspace/handle/10045/80509

[7] C. A. Quinayás-Burgos, C. A. Gaviria-López, "Sistema de identificación de intención de movimiento para el control mioeléctrico de una prótesis de mano robótica," Ing. y Univ., vol. 19, no. 1, 2015. [Online]. doi: 10.11144/Javeriana.iyu19-1.siim

[8] D. Bansal and R. Mahajan, "EEG-Based Brain-Computer Interfacing (BCI)," Elsevier Inc., pp. 21 - 71, 2019. [Online]. doi: https://doi.org/10.1016/B978-0-12-814687-3.00002-8

[9] G. Rodríguez-Bermúdez, P. García Laencina, D. Brizion, and J. Roca, "Adquisición, procesamiento y clasificación de señales EEG para diseño de sistemas $\mathrm{BCl}$ basados en imaginación de movimiento," Rev. VI Jornadas Introd. a la Investig. la UPCT, vol. 6, pp. 10-12, 2013. [Online]. Available: https://www.researchgate.net/publication/260872345_Adquisicion_procesamiento_y_clasificacion_de_senales_EEG_para_diseno_de_sistemas_BCl_basados_en_ imaginacion_de_movimiento

[10] B. J. Edelman, J. Meng, D. Suma, C. Zurn, E. Nagarajan, BS Baxter, CC Cline, y B. El, "Noninvasive neuroimaging enhances continuous neural tracking for robotic device control," Science Robotics, vol. 4, no. 31, 2019. [Online]. doi:: 10.1126 / scirobotics.aaw6844

[11] J. Minguez, "Tecnología de Interfaz Cerebro - Computador," Dep. Inform. e Ing. Sist. Zaragoza, pp. 1-12, 2012. [Online]. Available: https://webdiis.unizar.es/ jminguez/Sesion001_UJI.pdf

[12] M. Balcells and V. Cisteré, "Imagen de archivo Historia de la Electroencefalografía en España: introducción y evolución," Neurosci. Hist., vol. 2, no. 1, pp. 38-42, 2014. [Online]. Available: http://nah.sen.es/vmfiles/abstract/NAHV2N1201438_42ES.pdf 
[13] L. A. Moreno-Cueva, C. A. Peña Cortés, H. G. Gonzáles-Sepúlveda, "Integración de un sistema de neuroseñales para detectar expresiones en el análisis de material multimedia," Revista Facultad de Ingeniería, UPTC, vol. 24, no, 38. [Online]. doi: 10.19053/01211129.3156

[14] R. Raj, S. Deb, and P. Bhattacharya, "Brain Computer Interfaced Single Key Omni Directional Pointing and Command System: A Screen Pointing Interface for Differently-abled Person," Procedia Comput. Sci., vol. 133, pp. 161-168, 2018. [Online]. doi: https://doi.org/10.1016/j. procs.2018.07.020

[15] A. Asif, M. Majid, and S. M. Anwar, "Human stress classification using EEG signals in response to music tracks," Comput. Biol. Med., vol. 107, no. February, 2019. [Online]. doi: https://doi. org/10.1016/j.compbiomed.2019.02.015

[16] J. H. Yu and K. B. Sim, "Classification of color imagination using Emotiv EPOC and event-related potential in electroencephalogram," Optik (Stuttg). vol. 127, no. 20, 2016. [Online]. doi: https://doi.org/10.1016/j.ijleo.2016.07.074

[17] F. Gómez, J. Leonardo, "Análisis de señales EEG para detección de eventos oculares, musculares y cognitivos," Biblioteca ETSI Industriales, pp. 8-9, Sep. 2016. [Online]. Available:http:// oa.upm.es/44379/1/TFM_LEONARDO_JOSE_GOMEZ_FIGUEROA.pdf

[18] L. Bi, A. Feleke, and C. Guan, "A review on EMG-based motor intention prediction of continuous human upper limb motion for human-robot collaboration," Biomed. Signal Process. Control, vol. 51, pp. 113-127, 2019. https://doi.org/10.1016/j.bspc.2019.02.011

[19] M. Tavakoli, C. Benussi, and J. L. Lourenco, "Single channel surface EMG control of advanced prosthetic hands: A simple, low cost and efficient approach," Expert Syst. Appl., vol. 79, pp. 322-332, 2017. [Online]. doi: https://doi.org/10.1016/j.eswa.2017.03.012

[20] C. Cipriani et al., "Online Myoelectric Control of a Dexterous Hand Prosthesis by Transradial Amputees," IEEE Transactions on Neural Systems and Rehabilitation Engineering, vol. 19, no. 3, 2011. [Online]. doi:: 10.1109/TNSRE.2011.2108667

[21] M. Jochumsen, A. Waris, and E. N. Kamavuako, "The effect of arm position on classification of hand gestures with intramuscular EMG," Biomed. Signal Process. Control, vol. 43, 2018. [Online]. doi: https://doi.org/10.1016/j.bspc.2018.02.013

[22] M. A. A. Kasim et al., "User-Friendly LabVIEW GUI for Prosthetic Hand Control Using Emotiv EEG Headset," Procedia Comput. Sci., vol. 105, no. December, 2017. [Online]. doi: https://doi. org/10.1016/j.procs.2017.01.222 
[23] R. Alazrai, H. Alwanni, and M. I. Daoud, "EEG-based BCl system for decoding finger movements within the same hand," Neurosci. Lett., vol. 698, no. December, 2019. [Online]. doi: https://doi.org/10.1016/j.neulet.2018.12.045

[24] M. D. del Castillo, J. I. Serrano, J. Ibáñez, and L. J. Barrios, "Metodología para la Creación de una Interfaz Cerebro-Computador Aplicada a la Identificación de la Intención de Movimiento," RIAI-Rev. Iberoam. Autom. elnform. Ind., vol. 8, no. 2, 2011. [Online]. doi: 10.1016/ S1697-7912(11)70030-9

[25] G. D. I. Gib, J. Giraldo-leiva, and M. A. Becerra, "Brain Computer Interface Based On Eeg Signals For Motion Control Of Hand Prosthesis Using Anfis," pp. 59-64, 2013. [Online]. Available: https://dialnet.unirioja.es/servlet/articulo?codigo=4776223

[26] C. D. Virgilio G., J. H. Sossa A., J. M. Antelis, and L. E. Falcón, "Spiking Neural Networks applied to the classification of motor tasks in EEG signals," Neural Networks, vol. 122, 2020. [Online]. doi: https://doi.org/10.1016/j.neunet.2019.09.037

[27] G. Lange, C. Y. Low, K. Johar, F. A. Hanapiah, and F. Kamaruzaman, "Classification of Electroencephalogram Data from Hand Grasp and Release Movements for $\mathrm{BCl}$ Controlled Prosthesis," Procedia Technol., vol. 26, pp. 374-381, 2016.

[28] J. E. Vargas Soto, M. A. Traslosheros, J. M. Ramos, J. E. Orozco Ramirez, "Sinergia Mecatrónica," Asociación Mexicana de Mecatrónica A.C, pp. 517, May. 2019. [Online]. Available: http://www. mecamex.net/Libros/2019-Libro-SinergiaMecatronica.pdf

[29] T. Talamillo García, "Manual básico para enfermeros en electroencefalografía," Enfermería Docente, pp. 29-33. [Online]. Available: http://www.sspa.juntadeandalucia.es/servicioandaluzdesalud/huvvsites/default/files/r evistas/ED-094-07.pdf

[30] M. E. Hussein and G. Brooker, "3D Printed Myoelectric Prosthetic Arm," pp. 87, Oct. 2014. [Online]. Available: https://www.academia.edu/39599212/3D_Printed_Myoelectric_Prosthetic_Arm_3D_Printed_Myoelectric_Prosthetic_Arm_i 